\title{
POLITICAL SCIENCE
}

\section{Суб’сктивний вимір гібридної війни: алгоритм впливу і захисні механізми}

\author{
Б. Калініченко \\ Кафедра державної служби, публічного адміністрування і політології Черкаського національного університету \\ імені Богдана Хмельницького, Черкаси, Україна. \\ Paper received 06.09.19; Accepted for publication 26.09.19.
}

https://doi.org/10.31174/SEND-HS2019-214VII36-11

\begin{abstract}
Анотація: у статті аналізуються процеси впливу гібридної війни на особистість. При цьому підкреслено, що впливами охоплено увесь духовний простір особистості людини і на кожному його організаційному рівні мають місце «свої» маніпуляційні виклики: у горизонті підсвідомості - збуджуються агресивні сегменти психосфери соціуму; у горизонті свідомості - концентруються фейкові новини і відверта медіапропаганда антинаціональних цінностей суспільства в якому живе людина; у горизонті надсвідомості - культивуються спотворені ідеали минулого і активізуються зразки антисуспільної поведінки. Захистити себе особистість може тільки системою внутрішньоособистісних фільтрів, досягненням певної зрілості організаційної свідомості або сталими позитивними особистісними ідеалами.
\end{abstract}

Ключові слова: людина, суспільство, інформачія, знання, підсвідомість, свідомість, надсвідомість, смисл, архетип, символ, війна, медіапропаганда.

Постановка проблеми. Парадокс політичного простору планети на початку XXI століття полягає у тому, що світова спільнота готується опанувати Ближній космос, виношує ідею Світового уряду і планетарного організму як цілісності, що веде до становлення Планетарної особистості, а в цей же час деякі державні політичні структури агресивно культивують все нові і нові гібридні форми війни, знімають 3 місця і женуть по світу мільйони людей у пошуках роботи і засобів виживання. Постає питання чому так відбувається?

Справа зайшла так далеко, що Генеральний секретар ООН Антоніо Гуттеріш вважає, наприклад, що світ стикнувся з необхідністю встановити дозволені рамки міждержавних кібернетичних атак. Про це він заявив 16 лютого 2018 року у виступі на 54-й Мюнхенській безпековій конференції, повідомляє з Мюнхена кореспондент «Європейської правди». Він нагадав, що взаємні удари у кіберпросторі вже стали реальністю. «Настав час говорити про міжнародні правові рамки ведення кібернетичної війни», - наголосив генсек ООН [3]. Він запропонував розпочати дискусію з цього приводу на майданчику Генасамблеї ООН. Як відомо, існують схожі за назвою міжнародні правила збройних конфліктів. «Закони та звичаї ведення війни» понад 100 років тому були закріплені низкою міжнародних конвенцій, які відтоді багато разів модифікувалися. Їх порушення є міжнародним злочином.

Аналіз досліджень і публікацій. Відповіді на ці питання слід шукати у глибинах психосфери соціуму i суб'єктивованого процесу смислопородження у структурі особистості людини. На практиці виявляється, що полем битви у сучасних інформаційних, кібернетичних гібридних війнах за панування у суспільстві, стали глибинні пласти підсвідомості пересічної людини. Це втручання у мислення людини побудовано на існуванні технологічного зв'язку політичного простору суспільства людини. Для того щоб розібратися у цьому процесі треба звернутися, на нашу думку, до глибинних процесів смислопородження, смислотворення, смислоусвідомлення і смислобудівництва, що притаманні кожній психічно здоровій пересічній людині.

Роль активності самого суб’ єкта в породженні смислів особливо підкреслюють Дж. Бьюдженталь, Дж. Келлі, С. Мадді, Л. Томас, В. Франкл, Ш. Харрі-Аугстайн, М. Чиксентмихалі, Дж. Шоттер. Соціокультурну детермінацію смислів констатують Р. Мей, Я. Смедслунд, Л. Томас, Ф. Фенікс, Ш. Харрі-Аугстайн, Р. Харре, М. Чиксентмихалі, К. Г. Юнг, при цьому особливу роль навчання і самонавчання в породженні смислів зазначають Ф. Фенікс, Л. Томас, Ш. Харрі-Аугстайн, а також Дж. Шоттер. К. Левін звертає увагу на вплив інших людей на породження смислів (валентностей) у вигляді наказу, заборони або прикладу. Невичерпним і безцінним джерелом тут $є$ праці О. М. Леонтьєва, Д.О.Леонтьєва, В. Васютинського, О.Донченко та ін..

Мета роботи полягає у відтворенні змін у духовному світі пересічної людини, що відбуваються під тиском гібридної війни, що спонукає іï функціонувати у алгоритмі спроектованим агресором і у визначені засобів її особистісного захисту від небажаного втручання сторонніх.

Результати теоретичного дослідження. Загальновідомо, що тотальний наступ на пересічну особистість у вкрай агресивній формі сьогодні отримав загальну назву - гібридна війна. У залежності від класифікації ії параметрів ми маємо справу: з інформаційною війною, якщо для цього використовується інформаційний простір, наприклад, ЗМІ; кібервійною - якщо у цьому задіяні засоби Iнтернету і інші мережі, наприклад, типу «Фейсбук», або «Твіттер»; медіавійною - якщо головними інструментами впливу на людину використовуються специфічні медіазасоби; гібридною війна стає завдяки нечітким методам впливу на людину.

Загальний характер такого впливу - маніпуляційний. На рівні підсвідомості людини він збуджує сегменти архетипів страху і невпевненості у собі і у безпеці умов власного життєустрою у просторі територіальної громади і країни в цілому. Наприклад, стверджується, що Україна - це не самостійне утворення і що вона у принципі не може бути суверенною і незалежною державою.

Підключеність людини до психосфери соціуму виявляється через здібність людини розпаковувати смисли, або, іншими словами, розуміти та кодифікувати певним 
чином інформацію, отриману внаслідок діяльності людської свідомості. Тому виникає можливість розглядати людину як селективний, вірогіднісно заданий прояв семантичного поля [7; 8], що відіграє роль того середовища, через яке відбувається взаємодія людини та світу смислів за допомогою слів чи символів та їх розуміння.

Тут працює генотипічна інформація людського роду, що накопичена ним у ході тривалого власного культурноісторичного процесу. Наприклад чому у країнах колишнього СРСР не приживається ідея вестернізації образу життя населення. Скільки б нам не пропонували американські рецепти життя і якими б вони не були розумними, їх ще потрібно адаптувати до українських реалій. Причина полягає у тому, що «американський соціум не знає психосоціальних архетипових глибин, притаманних українському. Американці одразу починали 3 ліберального життєустрою, вони принципово не в змозі зрозуміти українську або російську психокультуру через відсутність у їхньому колективному несвідомому тоталітарного й авторитарного архетипів, а отже певних універсальних кумулятивних феноменів суспільної та індивідуальної свідомості»[4, с.51].

Тож у такому контексті смисли розуміються як генотипічна інформація, що міститься у знаках чи символах, де вона являє собою єдність континуальності (тобто семантики, змісту) та дискретності (тобто знаків, форми). Тому природа смислів може бути вираженою, як вважає В. Налімов, тріадою «смисл - текст - мова». За таких обставин $є$ сенс припустити, що в дискурсі досліджуваної проблеми або в медіапросторі, ця тріада працює, швидше за все, у зворотному напрямі, а саме: мова 3MI, Інтернету та інших медіаджерел - текст, що постійно реінтерпретується і є особистістю - сенс, що закладений в інформаційні концепти медіаджерел трансформується в мотив поведінки людини.

Зміна смислових акцентів (тобто важливості смислів) стає умовою виникнення нових текстів [7, с.154]. Коли ж розглядається ноосфера як сфера людського розуму, то текстом стає як свідомість окремої людини, так і колективна свідомість [7; 8].

На рівні свідомості людини вплив забезпечується тиском соціальної або так званої фенотипічної інформації. При цьому специфікою прояву влади медіа джерел над пересічною людиною є те, що пряме командування іiї поведінкою змінюється на психологічне навіювання i, як наслідок, проявляється на практиці безслівною покорою особистості телеглядача або навіть певної маси населення, закликам з боку медіаджерел. Влада ЗМІ над особистістю, що підпадає під ії вплив, реалізується завдяки властивостям фенотипічного потенціалу тексту, що закладений у повідомлення і який спрямований на формування у свідомості людини спотвореного суспільного ідеалу, наприклад, певного образу життя людини або відношення до власних органів державної влади. Це майстерно робиться у вигляді багато чисельних політичних шоу на телеекранах і в Інтернеті.

Отже, перебіг генотипової та фенотипової інформації, що забезпечують, з одного боку, поєднання біологічної людини із фізичним та семантичним світом, а $з$ другого, - підключення особистості до світу соціального завдяки ЗМI та Інтернету, забезпечується через посередництво психічного рівня, де виникають семантичні фільтри, що регулюють перехід інформації з рівня безсвідомого на рівень свідомості, таким чином селекціонуючи найбільш важливу для функціонування особистості інформацію.

Якщо обраний варіант не спрацьовує або відбувається зміна ситуації, то змінюється семантичний фільтр, тобто шукають інший принцип відбору інформації. Для цього витягуються все нові символи, наприклад, георгіївські стрічки або починає культивуватися ідея «бесмертного полку», потоком виливаються на населення усе нові і нові фейкові новини. Таким чином, підсвідомість людини знову занурюється у героїчне минуле і починає його натурально переживати.

Циркуляція фенотипової та генотипової інформації у просторі 3МI і Інтернету створює і відтворює енерго-інформаційне поле особистості як форми існування ії сутнісних сил. Умовою здійснення інформаційного обміну на рівні особистості при цьому стає розвиток здібностей суб'єкта, які обумовлюють можливість сприйняття, селекції, обробки, зберігання та продукування інформації, для реалізації чого в процесі інформаційного обміну формуються відповідні функціональні органи. Найбільш важливими серед них є, на думку В.Беха, механізми збудження, цілеутворення і смислопородження [1].

Узагальнення результатів цілої низки досліджень дали підстави В.Васютинському для «визначення кількох основних інтеракційних механізмів (радше сукупностей, класів механізмів) домінування-підпорядкування. По-перше, слід вести мову про механізми взаємної суб'єктної активації учасників взаємодії. Друга сукупність механізмів стосується взаємного узгодження позицій і статусів. Третя сукупність означає встановлення або порушення різних видів близькості-віддаленості між учасниками взаємодії, насамперед, просторової та психологічної. Четверта група механізмів, найчисленніша серед вивчених, зумовлює примусово-наказовообмежувальний модус владно-підвладної взаємодії з погляду панівної і підлеглої її сторін. П'ята група включає механізми, що роблять взаємодію емоційно насиченою і формують ії за шкалою «любов - ненависть» [2, с. 59].

Тут доречно звернути увагу на наявність у структурі організму людини інших психологічних механізмів, що обслуговують раціональну складову життєдіяльності пересічної людини, наприклад, породження смислу: замкнення життєвих відносин, індукція смислу, ідентифікація, інсайт, зіткнення смислів, надання смислу [6].

Треба окремо зазначити, що потоки фенотипічної інформації цілеспрямовано скеровуються на людину і несуть у собі активний пропагандистський матеріал маніпулятивного змісту і спрямованості. Це відмічають, наприклад, усі спостерігачі російсько-української гібридної війни.

За таких умов пересічна людина, на основі збудженого специфічного сегменту соціуму, що утримує руйнівні архетипи і пропагандистської атаки з боку агресора на рівні суспільного горизонту, формує у їі самосвідомості кінцевий продукт - спотворену модель соціально-політичного життя і тим самим остаточно програмує власну поведінку на користь агресора.

Ми бачимо, що в сучасній Україні на етапі сучасної соціально-політичної кризи поширені головні три типи поведінки - ідентифікація, індивідуалізація та девіація, серед яких найменш вираженим є ідентифікація: в суспільстві просто немає необхідної більшості. Консолідації, 
як ми вже констатували, потребувала влада, яка й досягала іiі епізодично, на етапах передвиборних марафонів. Зразу ж після них більшість ставала вже непотрібною. Засоби масової інформації іноді натякають на необхідність проведення якихось реформ, але водночас формують індивідуалізований і девіантний типи поведінки - як у владних структурах, так і в народі [4, с.100].

На рівні надсвідомості людини ми спостерігаємо наслідки реакції пересічної особистості на впливи гібридної війни завдяки функціонуванню трьох внутрішньоособистісних механізмів, а саме: самовизначення, самоактуалізації і самореалізації [1].

Надсвідомість - різновид неусвідомлюваного. До проявів надсвідомості можна віднести подолання виниклих світоглядних суперечностей, перші етапи творчого процесу (здогадки, осяяння, гіпотези, задуми та ін). П. Симонов вважає, наприклад, що надсвідомість на відміну від підсвідомості покликана не розвантажувати, а, навпаки, навантажувати свідомість роботою. Наслідком надсвідомості є багатоманіття різноспрямованих психологічних явищ у духовному просторі пересічної людини.

Надсвідомість завжди орієнтована на задоволення домінуючої потреби, конкретний зміст якої каналізує напрям «психічного мутагенезу». Таким чином, «психічні мутації» спочатку носять непередбачуваний, але невипадковий характер. Другим каналізуючим фактором є раніше накопичений досвід суб'єкта, зафіксований в його свідомості і підсвідомості, наприклад, негативна оцінка відсутності належної уваги органів державного управління до вирішення проблем Криму, донбаського регіону або Закарпаття.

Серед іiі механізмів, особливе місце займає принцип домінанти О.О.Ухтомського. Звернемо увагу на основні властивості домінантного вогнища, що встановлені О.О. Ухтомським: підвищена збудливість, інерція в часі (домінанта існує, хоча роздратування завелике) i, найголовніше, здатність інтегрувати зовнішні подразники, «самопідживлюватися ними» [10].

Атрибутивна властивість домінанти полягає в утриманні людини у стані безперервного збудження. Діяльність людини багато в чому визначається домінантою стійким осередком підвищеної збудливості в корі і/ або підкірці головного мозку. Це і є таємниче «щось». Домінантний осередок здатний інтегрувати зовнішні подразники до цієї домінантної потреби дію усіх інших подразників. При цьому виявляється, що «немає сенсу входити в суперечки і дебати тому, що, якщо склалася домінанта, iї не подолати словами і переконаннями, - вона буде ними тільки харчуватися і підкріплюватися. Це тому, що домінанта завжди самовиправдовується, і логіка - слуга ії», писав О.О. Ухтомський [10].

Це означає, що надсвідомість завжди «працює» на задоволення потреби, що стійко домінує в ієрархії мотивів даного суб'єкта. Гібридна війна спеціально вводить у надсвідомість пересічної людини хибний орієнтир і робить його домінуючою потребою. Ефект значно зростає, якщо агресору вдалося вплинути на масу людей, наприклад, як це було у випадку з відокремленням Криму.

Залежно від того, які властивості притаманні даному соціуму заангажованого гібридними технологіями людиною здійснюються вибір власної поведінки у новостворених умовах. Можна виділити такі адаптивні процеси, або типи, адаптивної поведінки людей [4, с.99-100]:
- ідентифікація (проста і складна) - найпоширеніший у суспільстві спосіб виживання («Я» - разом з більшістю; тип поведінки - поступливо-компромісний);

- індивідуалізація - форма виявлення зрілого «Я» людини, iіi «самості» («Я» саме по собі; тип поведінки відгородження від інших);

- інвестиція - найкорисніший для суспільства спосіб вирішення проблеми вибору; шлях вкладення особистісного потенціалу в реалізацію соціокультур- них, найважливіших для даного соціуму програм («Я» 3 тими, в кого є «здоровий глузд»; тип поведінки - колаборативний);

- маргіналізація - спосіб протистояти тотальній ідентифікації («Я» 3 тими, хто проти більшості; тип поведінки - негативістський);

- девіація - результат деструктивного виходу людини iз власного внутрішнього конфлікту, який переростає в агресивно-руйнівну поведінку («Я» проти всіх; тип поведінки - руйнівний).

Процеси адаптації - це врешті архетипи соціальної поведінки, за допомогою яких людина несвідомо конструює свою життєву реальність, свій життєвий шлях, зберігає той спільний для людини і соціуму простір сенсу, втрата якого ініціює життєву кризу індивіда й актуальну потребу в будь-якому возз'єднанні з соціумом. Жодний індивід, жодна соціальна група неспроможні вільно, лише за власним бажанням, винайти нові (такі, яких би не було в архетипі) форми вирішення конфліктів і дисонансів. За думкою Д. Гоманса, чим частіше певний тип поведінки винагороджувався в певному соціумі, тим поширенішим він стає у ньому, створюючи відповідне соцієтальне поле.

Перелічені процеси є не що інше, як типи поведінки, більш-менш поширені в соціумі. Обличчя соціумів можна диференціювати залежно від того, який саме тип адаптивної поведінки превалює там чи там. Особливо чітко ця різниця проявляється на етапах трансформації суспільства, коли кожний мусить зробити власний вибір, від якого зрештою залежатиме загальний візерунок соціального руху. Макропроцеси адаптації або соцієтальні процеси в кінцевому підсумку визначають здатність до розв'язання соціального конфлікту на рівні суспільства в цілому.

Війна ведеться, як бачимо, з використанням усього накопиченого медіаресурсу, що $є$ у розпорядженні агресора. Окрема людина може захистити себе від агресивного впливу ЗМІ шляхом формування в себе високої політичної культури, зрілої організаційної свідомості [5] і активізації власної системи внутрішньоособистісних фільтрів [1]. Або шляхом ідеологічного несприйняття агресивної поведінки сусіда і його прибічників, як у органах державної влади своєї країни, так і у просторі власної територіальної громади.

3 вищевикладеного можна зробити наступні висновки:

по-перше, гібридна війна націлена на цілеспрямоване використання смислогенезу у якості субстанційного хвилеподібного впливу на підсвідомість, свідомість і надсвідомість особистості шляхом маніпуляції смислами у відповідності до умов перебування конкретної людини або територіальної громади, одночасно захоплюючи архитепічний, нормативний і інформаційно-знаковий горизонти системи саморегуляції життєдіяльності 
пересічної людини;

по-друге, у випадку, коли об'єктом агресивного впливу є пересічна особистість, зусилля спрямовані на цільове збудження обраних сегментів психосфери конкретного соціуму з метою ангажування підсвідомості особистості у горизонті звернення до певних архетипів для чого використовується система символів, на які здатна відгукнутися об'єкт впливу;

по-третє, у горизонті функціонування свідомості пересічної людини запускається система фенотипічної інформації фейкового спрямування з метою підтримання тих стереотипів і ідеалів, що спливають вже з власної 3 підсвідомості людини і вона стає палаючим факелом протесних настроїв, що значно посилюються недолугими діями органів у правління власної держави або території;
- по-четверте, надсвідомість людини, що завжди орієнтована на задоволення домінуючої потреби, конкретний зміст якої каналізує напрям «психічного мутагенезу» i спирається на раніше накопичений досвід суб'єкта, що зафіксований в його свідомості і підсвідомості, наприклад, відсутність належної уваги діючих органів державного управління до вирішення проблем Криму, донбаського регіону або Закарпаття;

по-п'яте, захистити себе людина може тільки шляхом використання системи внутрішньоособистісних фільтрів, зрілою організаційною свідомістю, відповідною політичною культурою, нарешті, зверненням до позитивного суспільного ідеалу особистості XXI століття, справедливої європейської держави і щасливого суспільства.

1. Бех В. П. Человек и Вселенная/ В.П. Бех. - Запорожье: РА «Тандем-У», 1998. - 144 с.

2. Васютинський В. Інтеракційна психологія влади/ В. Васютинський. - К.: Київський славістичний ун-т, 2005. - 492 с.

3. Генсек ООН: настав час запровадити правила ведення кібервійни. Заголовок 3 екрану. Режим доступу://http://www.eurointegration.com.ua/news/2018/02/16/707 $7641 /$

4. Донченко О., Романенко Ю. Архетипи соціального життя і політика (Глибинні регулятиви психополітичного повсякденна): Монографія. - К.: Либідь, 2001. - 334 с.

5. Козловська Г. В. Організаційна свідомість: індивідуальне і суспільне: [монографія]/ Г.В. Козловська. - К.: Вид-во НПУ

\section{ITEPATУРA}

імені М.П. Драгоманова, 2007. - 203 с.

6. Леонтьев Д. А. Психология смысла: природа, строение и динамика смысловой реальности/ Д.А. Леонтьев. - М.: Смысл, 1999. $-487 \mathrm{c}$.

7. Налимов В. В. Реальность нереального. Вероятностная модель бессознательного (Бессознательное как проявление Семантической Вселенной)/ В.В. Налимов, Ж.А. Дрогалина. - М.: Изд-во “Мир идей”, АО АКРОН, 1995. - 432 с.

8. Налимов В. В. Спонтанность сознания/ В.В. Налимов. - М.: Прометей, 1989. - 287 с

9. Неусвідомлені психічні явища. Режим доступу: http://polkaknig.com.ua/article.php? book $=359$ \&article $=19538$

10. Ухтомский А.А. Доминанта. - М.; Л.: Наука, 1966. - 271 с.

\section{REFERENCES}

1. Bekh V. P. The Human and the Universe/ B.P. Bekh. Zaporozhye: RA "Tandem-U", 1998. - 144 p.

2. Vasyutinsky V. Interaction psychology of the authorities/ V. Vasyutinsky. - K.: Kyiv Slavonic University, 2005. - 492 p.

3. UN Secretary General: the time has come to set the rules for cyberwar. Title from the screen. Access mode://http://www.eurointegration.com.ua/news/2018/02/16/707 $7641 /$

4. Donchenko O., Romanenko Yu. Archetypes of social life and politics (Deep regulating means of the psycho-political routine): Monography. - K.: Lybid, 2001. - 334 p.

5. Kozlovska G. V. Organizational Consciousness: Individual and Social: [monography]/ G.V. Kozlovska. - K.: Published by
National Pedagogical Dragomanov University, 2007. - 203 p.

6. Leontyev D. A. Sense Psychology: Nature, Structure and Dynamics of the Sense Reality/ D.A> Leontyev. - M.: Smysl, 1999. - 487 p.

7. Nalimov V. V. Reality of the Unreal. Probabilistic Model of the Unconscious (Unconscious as Manifestation of the Semantic Universe)/ V.V. Nalimov, Zh.A. Drogalina. - M.: Publ. "Mir idei”, JSC AKRON, 1995. - 432 p.

8. Nalimov V. V. Spontaneity of the Conscious/ V.V. Nalimov. - M.: Prometey, 1989. - 287 p.

9. Unconscious Mental Phenomena. Access mode: http://polkaknig.com.ua/article.php? book $=359$ \&article $=19538$

10. Ukhtomsky A.A. The Dominant. - M.; L.: Nauka, 1966. - 271 p..

\section{Subjective measurement of hybrid war: algorithms of influence and protective mechanisms}

\section{B. Kalinichenko}

Abstract: The article analyzes the processes of the hybrid war influence on a person. At the same time, it is stressed that all the spiritual space of a person's personality is covered by influences and at each of its organizational levels there are "own" manipulative challenges: in the horizon of the subconscious, aggressive segments of the psychosphere of society are excited; in the horizon of consciousness - fake news and open media propaganda of anti-national values of the society in which a person lives are concentrated; in the horizon of the superconscious - the distorted ideals of the past are cultivated and patterns of antisocial behavior are activated. Protect yourself, the person can only a system of intrapersonal filters, the achievement of a certain maturity of organizational consciousness or stable positive personal ideals.

Keywords: man, society, information, knowledge, subconsciousness, consciousness, superconsciousness, meaning, archetype, symbol, war, media propaganda. 